\title{
The Tendency of Primary School Teachers towards Teaching the Profession in Light of Some Variables
}

\author{
Amaal Al Masri \\ Assistant Professor, Princess Alia University College, \\ Al Balqa Applied University, Abu Hamed Al Ghazali St 15, \\ Amman, Jordan

\section{Mutaib Al-Otaibi} \\ Assistant Professor of Curriculum and Teaching Methods, \\ Amman Arab University, Jordan Street, \\ Jordan
}

DOI: https://doi.org/10.36941/jesr-2021-0145

\section{Abstract}

The study aimed to reveal attitudes in primary school teachers and their female teachers in the Mubarak AlKabeer educational district in Kuwait towards the teaching profession in light of some variables. To achieve the study's objectives, the researcher chose a random sample consisting of (400) teachers, and the researcher also designed a questionnaire consisting of (50) A paragraph that was judged, and the necessary honesty and consistency were given to it. The study found that all members of the study sample had a negative attitude towards the teaching profession and found no statistically significant difference between the average grades of primary school teachers and their teachers according to their literary and scientific specializations in the direction towards the teaching profession. In contrast, the study results showed that there are statistically significant differences between the average grades of teachers and the degrees of teachers towards the teaching profession and for the benefit of female teachers. The results also showed statistically significant differences for years of experience and in favor of those with experience (less than five years) in the direction towards the teaching profession. Therefore, the study recommended that the opportunity for teachers with long experience be given encouraging opportunities, motivation, and working to inform them of their importance, assigning them to tasks that satisfy their needs and desires, as well as spreading the spirit of respect for the teaching profession in the hearts of members of society as well as in the hearts of teachers who practice the profession of teaching.

Keywords: Tendency of Primary School Teachers, Teaching the Profession

\section{Introduction}

The teaching profession is one of the most important professions in society because it represents the basis for societies' progress and ensures the continuity of individuals in life. Achieving this end requires a set of qualities and skills that must be available in the teacher, which is the basis for building generations and societies and refining their personalities by transferring knowledge to the 
minds of his students, teaching them, and raising their awareness.

From this perspective, complying with the third Millennium requirements and seeking to reach the benefits from education excellence standards, education reform became an urgent need, which requires considerable attention in the development system of teacher's performance. That system is considered a sustainable professional development process because the teacher is the main pillar in the educational process and one of its essential incomes that contributes to enhancing the process outcomes (Al- Makhzoumi, 2007).

The global trend in the development of education in many countries today confirms that education as a profession is a type of service provided to students. This service requires teachers to have several specific technical knowledge and skills based on severe and continuous study and continuous scientific research and keeping pace with everything that is new but requires them to adhere to the ethics of the profession towards their work, students, and society (Obeidi and Ashour, 2020).

The fact indicates that teachers in most countries are satisfied with rehabilitation programs in Education Faculties. This may refer to the fact that these programs are more interested in teaching methods considering the cognitive and descriptive dimensions without any interest in providing them field experiences and consist appropriate orientations of similar teaching situations to the real situations and through it. The methods are subject to testing, supervising, and analyzing to enable teachers to improve their teaching performance and develop their tendency towards a teaching career. This kind of preparation is in line with the second wave of teaching skills at the end of the $2 \mathrm{o}^{\mathrm{th}}$ century, which is based on providing teachers with cognitive skills that enable them to provide their students in return with the right scientific way of thinking, be creative enough to solve their problem (Al-Bariri and Ishaq, 2010).

Obviously, under the light of changes in the role of the teacher, teacher word is no longer reflective to express the new missions of the teacher that are represented in creating an educational environment, simplifying the education process for students, testing their various levels, following up their progress, and guiding them to achieve the intended aims for communities' development. This all goes to the role of the teacher; he's considered the scientist, the employee, the doctor, the engineer, the judge, and all individuals of the community; this is the thing that requires serious attention as much as the importance of his responsibility as fully as possible. One of the most important features is giving him positive orientations towards a teaching career (Sykes, 2016).

The Research Problem

At a time when teaching was one of the main and essential careers to risen and develop communities, the demands to develop teaching career have been multiplied in all countries of the world, especially in the developing countries from what affirms and comply with what stated in the report of the international committee of the educational development " learn to be" in the 18th concept from the basic duties of the educators at present. Also, working on changing required qualifications and the attitudes for all jobs, for this basic purpose standard of education career shall be reviewed first and radically. (Al-Mjedil and Al-Sharia, 2012)

According to the importance of teachers' positive tendency towards their career, many Studies have been conducted in different countries with a serious interest in identifying their own tendency toward their career, study results of (Al-Rashed, 2003, Al Ajmi, 2007, Heij, 2009. Al-Mjedil and AlSharia, 2012) have shown that educational college students have a strong and positive tendency towards a teaching career, but my study results revealed (Abdel-Fattah, 2010) that they have a slight tendency. The researcher noticed through a prospective study conducted on 6o teachers that a high proportion of those teachers who have expressed a lack desire to teach, those results and many previous study results mentioned above prompted the researcher to study their attitudes toward the teaching career, so this study attempt to answering the following questions:

1. What are the tendencies of primary teachers in Mubarak Al-Kabir Educational toward the 
education career?

2. Is there any statistically significant difference at the level $(\alpha=0.05)$ in the attitudes of primary school teachers in the Mubarak Al-Kabeer educational district towards the teaching profession according to the gender variable (males, females)?

3. Are there any statistically significant differences at the level of $(\alpha=0.05)$ in the attitudes of primary school teachers in Mubarak Al-Kabeer educational district towards the teaching profession according to the variable of specialization (literary and scientific specialization)?

4. Are there statistically significant differences at the level of significance $(\alpha=0.05)$ in the attitudes of primary school teachers in the Mubarak Al-Kabeer educational district towards the teaching profession according to the years of experience variable (from 1 to less than five years, from 5 years - less than 10 Years, and more than ten years)?

\subsection{Limits and limitations of the study}

This study was limited to primary school teachers' males/females in the Mubarak Al-Kabeer district, the State of Kuwait, who teach students from (1-5) years old, so the generalizations will be limited to the study community only.

The attitude scale (the study tool) towards the teaching profession was applied to the study sample in the first semester 2019/2020, and thus the generalization of the study results depends entirely on its psychometric properties, which represent honesty and consistency.

\subsection{The Importance of the Study}

The importance of the study stems from the recognition of teachers' attitudes towards the teaching profession, because the nature of the attitude towards something determines the nature of the individual's interaction with this thing, or the topic, whether it was negative or positive, and to achieve the desired objectives. Therefore, it is imperative to know the nature of teachers' attitudes who practice the profession and work to support positive aspects and acknowledge the formation reasons of attitudes. The study results may help the educational institutions' decision-makers address negative attitudes towards the teaching profession and find effective solutions for them by analyzing their causes and developing the required plans to annihilate them, and on the other hand, to reinforce their positive attitudes.

\subsection{The Study Objectives}

This study aims to identify the attitudes of primary school teachers in the Mubarak Al-Kabeer educational district in the State of Kuwait towards the teaching profession and the importance of these attitudes in the practice of the field based on the assumption that an attitude is an actual act that stimulates and directs behavior. The teacher's efficiency measures the efficiency of any educational institution's quality, and that the teacher's efficiency and his pursuit of improving his performance is related to his attitudes towards his profession.

Developing proposals and instructions in the light of the study results that contribute to improving the various aspects of preparation for the members of this profession.

The results of this study will open the way for other studies related to the teaching-learning process.

\subsection{Terminology of the Study}

The trend towards the teaching profession

Attitude is defined as "the tendency of a person towards the goal of what he wants to reach, whether it is in a negative or positive degree (Abla, Kayash and Bin Khaled, 2020) 
As for the attitude towards the teaching profession: it is the professor's attitude towards the teaching profession, and this attitude appears in the extent to which he accepts or rejects this profession, as well as the extent to which he appreciates its importance (Tayyab, 2012).

The trend is defined procedurally as the degree that the teacher obtains through his answers to the paragraphs of the study tool used in this study related to the trend towards the teaching profession.

Primary school teachers and female teachers are male and female teachers who teach any subject in the primary grades, including academic, professional, or informational knowledge.

Theoretical framework.

\subsection{Theoretical Framework and Previous Studies}

It includes two parts, the first is related to the theoretical literature related to the attitude towards education, and the second part is related to previous studies related to the subject of the study.

\section{Theoretical Framework and Previous Literature}

\subsection{Theoretical Framework}

\subsubsection{Attitudes towards the Teaching Profession}

Directions consist of several components:

- The cognitive component includes the ideas, information, experiences, and attitudes that the student is exposed to during his studies at the university or school, which affect his view of the teaching profession, leading to the formation of certain trends.

- The emotional component, which includes the emotional aspect, helps determine the type of student's attachment to the teaching profession; that is, it includes giving preference (Tayyab, 2012).

Choosing a student with a willingness and a positive attitude towards the teaching profession, with the availability of other characteristics, creates a match between the right person and the right place. This achieves the goals of both the individual and the place of study, reducing educational, psychological, and economic waste or loss. On the other hand, there is no doubt that if the student chooses a field that is not compatible with him, he may face failure in addition to the feelings he feels of inferiority, inferiority, and deprivation of excellence, which affects the decline in scientific competence and productivity, and helps to waste the effort of the individual and the institution (Tayyab, 2012).

\subsubsection{The Importance of Attitudes towards the Teaching Profession}

The success and quality of education are highly dependent on the teacher (Musa \& Bichi 2015). Therefore, if future teachers have positive attitudes towards education, this increases the possibility of their ability to raise the motivation of their students to learn, as the positive attitudes of teachers help in forming effective communication with students, and thus diversity in educational situations (Andronache et al., 2014).

In addition, the attitudes of students or teachers towards the teaching profession help develop the cognitive aspects so that they accept the curricula more, enjoy studying it and feel its simplicity (Al-Mjedil and Al-Sharia, 2012). Sivacumar (2018) states that the positive attitude reflects a measure of optimism among its owner. Therefore, due to his positive attitude towards his profession, the optimistic teacher will work to create a peaceful and stable educational environment that helps develop the students' scientific level and develops their various abilities and skills. Shaheen (2010) 
links between the success of the educational process and the attitudes of future students in the field of education, as he mentions that the presence of positive attitudes towards that profession encourages the acquisition of the skills of this profession, which the student needs in the future. Ahmed and Zumrud (2014) confirm this point of view where they mentioned that the positive attitudes of student teachers are considered a basic general for what they called (professionalization), meaning that the professional career future with its various skills, is formed through positive attitudes and that student teachers will be able to Carry out their professional roles effectively and efficiently. Therefore, the attitudes towards the teaching profession must be positive, and that future teachers have tendencies and acceptance of them. It is also essential to develop these trends, as recommended by some studies, which is that developing attitudes towards the teaching profession is essential to the teaching and learning process (Santillan et al., 2012).

The researcher believes that the importance of attitudes towards the teaching profession among teachers can be summarized as follows:

A. It helps the teacher to adapt to the educational process and strive to demonstrate teaching skills.

B. Raising the teaching efficiency of teachers in the personal as well as the academic aspects.

C. Through the positive giving of teachers, this is reflected on schoolchildren with a positive performance.

\subsection{Previous Studies}

Al-Ruz and Mraje' (2019) conducted a study to reveal the attitudes of education college students (AlBayda) at Omar Al-Mukhtar University - Libya towards the teaching profession. The study sample consisted of (286) male and female students from all academic years. The researchers developed a scale to measure attitudes towards the teaching profession on University students; the results of the study concluded that all members of the study sample have a negative attitude towards the teaching profession, and also found that there are no statistically significant differences between the mean scores of the scientific department's students and literary departments students towards the teaching profession. In contrast, statistically significant differences appeared between students' average grades in the first and second years, and the third and fourth years, towards the teaching profession, in advantage for the first and second-year students.

Abdul-Rahman (2014) conducted a study to know the general orientation of teachers 'attitudes at the secondary stage towards the teaching profession in the state of Gezira. The study sample consisted of (500) male and female teachers, and the researcher developed a scale to measure attitudes towards the teaching profession. The study found that the general orientation of male and female teachers 'attitudes towards the teaching profession is positive. However, it also found statistically significant differences in the total score of male and female teachers' attitudes attributed to the gender variable (males, females), and these differences are an advantage for females.

Al-Mjedil and Sharia (2012) conducted a study aimed at exploring the attitudes of tutor students in the College of Education - Kuwait University and in the College of Education in Al-Hasakeh Euphrates University towards the teaching profession, to achieve the goal of the study, the study sample consisted of (792) male and female students, of whom (403) Male and female students from the College of Education - Kuwait University and (389) male and female students from the College of Education in Al-Hasakah - Euphrates University. The two researchers prepared a questionnaire. The researchers reached several results, the most important of which are: that the gender variable impacts tutor students 'attitudes towards the teaching profession in both the two study samples and these differences favor female students. The variable of specialization did not affect the attitudes of tutor students towards the teaching profession in both samples of the study; also, the academic year variable did not show any effect on the sample attitudes of the enrolled students in the Faculty of Education Al-Hasakah - Euphrates University.

Bayraktar (2012) conducted a study aimed at identifying the attitudes of the Education college 
students at the University of Mosul towards the teaching profession; to achieve the study's objectives, he chose a sample of (8o) students from all departments. The results indicated that there is an increase in students 'tendency towards the teaching profession, and there are no statistically significant differences between first- and fourth-year students towards the teaching profession. At the same time, there were statistically significant differences between students of literary majors and scientific majors, also between males and females in advantage for males.

Nouri (2011) conducted a study aimed at measuring students' attitudes of the Physics Department, College of Education, University of Basra, towards the teaching profession; to accomplish a study, she chose a sample of (137) students from different stages. The study results indicated that the sample students 'attitudes were negative towards the teaching profession, and there were no statistically significant differences according to the gender variable and the academic stage variable (first - fourth) towards the teaching profession.

Al-Amayreh and Al-Asha (2009) conducted a study aimed at finding out the attitudes of primary school teachers (males and females) in Jordan towards the teaching profession, and to achieve the objectives of the study, the two researchers chose a sample of (3197) male and female teachers, as well as designed a questionnaire consisting of (51) items. The results of the study showed that the level of attitudes of primary school teachers (males and females) to the teaching profession was a low performance on the overall degree, and according to the gender variable, there were statistically significant differences in advantage for females. Also, the results showed statistically significant differences according to the years of experience variable, in favor of those with less experience.

Al-Faqih (2009) conducted a study to reveal the attitudes of female students of the Teachers College in Misurata towards the teaching profession, and to achieve the objectives of the study; he chose a sample of (390) students. The study results indicated that the attitudes of female students towards the teaching profession were positive in the social and economic fields in general and that there are statistically significant differences among first- and fourth-year female students towards the teaching profession in favor of fourth-year female students. At the same time, there are no differences attributed to academic specialization among female students in the teaching profession.

Khalil and Sherir (2008) conducted a study to find out the relationship between job satisfaction and some variables among teachers. The study sample consisted of (360) female and male teachers from Palestinian Authority schools. The two researchers used the descriptive-analytical approach. The study results showed statistically significant differences in job satisfaction as a whole in favor of females, holders of the intermediate diploma, and the lower basic stage. However, the results also showed statistically significant differences in the fields: the nature of work and its conditions, the relationship with officials, the females' advantage with an intermediate diploma, and the lower basic stage. On the other hand, the results also showed no statistically significant differences for the effect of the experience variable on job satisfaction.

Al-Khalidi (2013) conducted a study to know the attitudes of secondary school teachers (males and females) in Jordan towards the teaching profession. To achieve the aims of the study, a sample consisting of (312) teachers from Amman's first and second education schools was chosen, and the questionnaire used a method for its study, as it also used a descriptive survey approach. The study results showed that the total score of teachers 'attitudes was moderate, while it was low in the field of material aspects. The results also showed on the fifth field related to the social status of the teaching profession according to the variable of teaching experience and for the benefit of a group of fewer than five years.

Kyriacou and Kunc (2007) conducted a study exploring the expectations of new teachers and their perspectives towards the teaching profession. The study sample consisted of (28) junior high school teachers pursuing postgraduate studies in education and teacher training in three universities in Northern England, and a descriptive survey method was used to achieve the study's objectives. The most prominent results of the study showed that the most aspect of the teaching profession that teachers feel comfortable with is the joy they get when their students achieve impressive results in 
public examinations and that the worst aspect of the teaching profession is the large teaching load and the amount of administrative and technical work in the schools they work at.

Osunde and Lzeevbugie (2006) conducted a study to identify the teachers' attitudes towards the teaching profession. The study sample consisted of (6oo) primary school teachers, and the results showed a decrease in teachers' tendency towards their profession and their low perception of it.

Al-Mjedil (2006) conducted a study to identify tutors' attitudes in the Faculties of Education towards the teaching profession and the Education Faculties performance' evaluation towards attitudes stimulating among students. The study sample consisted of (330) students. The results showed no statistically significant differences between the attitudes of males and females towards the teaching profession and the absence of differences between school years towards the teaching profession. At the same time, there were statistically significant differences between literary and scientific disciplines in advantage for literature towards the teaching profession.

Al-Shahwani (2004) also conducted a study to identify the student teachers 'attitudes towards the teaching profession and achieve the study's objectives; he selected a sample of (131) tutor students. The results showed a decrease in students 'general tendency towards the teaching profession and no difference in the degrees of students' orientation towards the teaching profession, compared with specialization and the number of courses. In addition, the results showed a positive correlation between student teachers 'attitudes toward the teaching profession and the GPA and the existence of a relationship, a positive correlation between achievement in the field of the study and the attitude towards teaching.

Al-Sharaa and Al-Baqer (200o) conducted a study to identify the attitudes of male and female teachers of the Ministry of Education and Higher Education in the State of Qatar towards the teaching profession. The study sample consisted of (356) male and female teachers, and the two researchers used descriptive and analytical methods. The results showed that teachers' attitudes towards the teaching profession are less than the socially and educationally acceptable level and that female teachers' attitudes toward the teaching profession are better than male teachers' attitudes toward the profession. Furthermore, the results showed statistically significant differences in teachers' attitudes toward the teaching profession compared with the variable of the school stage in favor of the stage Elementary, according to the variable of experience in favor of the least experienced. However, the advantage goes for the highest income according to the income variable.

\subsection{Commentary on previous studies}

The presentations of the studies were all aimed at revealing attitudes towards the teaching profession, and these studies came as follows:

Some studies dealt with teachers 'attitudes towards the teaching profession, and among these studies is the study (Al-Amayreh and Asha (2009), Al-Faqih (2009), Kyriacou and Kunc (2007), the results of these studies showed that there is a positive attitude towards the teaching profession in the study samples. As for the studies Al-Ruz Mraje' (2019); Al-Mjedil and Al-Sharia (2012); Bayraktar (2012); and Al-Shahwani (2004); Nouri (2011), they were conducted on colleges education students. Relating the rest of the studies, there are differences in the teaching profession due to the variable of the academic major. In contrast, the results of the study of Al-Mjedil and Sharia (2012) and Bayraktar (2012) showed differences in the scientific and literary majors towards the teaching profession. This study was distinguished from previous studies in that it explored elementary school teachers' attitudes towards the teaching career, whose educational experience ranged from (1 - more than ten years).

\section{Method and Procedures}

To achieve the objectives of the current study, a descriptive research method of the (survey) type was followed, which is a method that relies on studying the reality or phenomenon as it exists in reality 
and is concerned with being an accurate description, through a qualitative expression that describes the phenomenon and explains its characteristics, or the quantitative one which gives a numerical description showing the magnitude of the phenomenon (Al-Jadri, 2007).

\subsection{The Population of the Study}

The study community is consisted of all primary school teachers and female teachers from government schools in the Mubarak Al-Kabeer educational district, a total of $(2,950)$ male and female teachers, as the number of male teachers reached $(1,200)$ teachers, representing $41 \%$ of the total number. In comparison, the number of female teachers reached (1750) teachers, representing 59\% of the total number of the study population.

\subsection{The Study Sample}

A proportional stratified random sample of (14\%) was taken from the community of male and female teachers and consisted of (400) teachers from the total study population. The teachers were selected from their varied communities in a simple random manner, and the study sample consisted of (170) male teachers and (230) female teachers. And Table (1) shows the distribution of the sample's individuals according to the study's variables.

Table 1: Distribution of study sample individuals according to study variables, number, and percentage

\begin{tabular}{llcc} 
Variables & Categories & Number & Percentage \\
\hline Gender & Males & 170 & $\% 34$ \\
& Females & 230 & $57 \%$ \\
& Total & 400 & $\% 100$ \\
\hline Major & Literary Majors & 210 & $52.50 \%$ \\
& Scientific Majors & 190 & $\% 47.50$ \\
& Total & 400 & $10 \%$ \\
\hline Years of experience & 1-less than 5years & 98 & $\% 25$ \\
& From 5 - less than 10 & 148 & $37 \%$ \\
& More than 10years & 154 & $38 \%$ \\
& Total & 400 & $100 \%$ \\
\hline
\end{tabular}

\subsection{The Study Tool}

To achieve the aims of the study, the researcher developed a tool to measure the attitudes of male and female teachers in the Mubarak Al-Kabeer educational district towards the teaching profession by briefing the researcher on several previous studies questionnaires: (Al-Amayreh and Al-Asha, 2009), (Al-Khalidi, 2013), (Al-Ruz and Mraje', 2019), (Al-Mjedil and Al-Sharia, 2012), (Abdul-Rahman, 2014), and the questionnaire included in its initial form (6o) paragraphs distributed over the following six fields of study: nature of work, self-satisfaction, financial aspects, relationship with colleagues and bosses, the future of the career, society's view of the teaching career.

The subject responds to five alternatives according to Likert, which fall according to the following (strongly agree, agree, neutral, disagree, strongly disagree). A score of $(1,2,3,4,5)$ is given respectively in the case of positive statements, and is reflected in the case of negative statements, also the lowest score obtained by the respondent is $(50)$, and the highest score is $(250)$. Therefore, the value of the hypothetical average (150), which is the cut-off point for interpreting the results, if the average of the sample members exceeds it, then the sample attitude is positive towards the teaching career; however, if it is less than the assumed average, the sample will be negative towards the teaching profession. 
To ensure the efficiency of the study method (scale), the researcher verified the validity and Constancy by the following:

After verifying the psychometric efficiency of the scale, the researcher conducted an exploratory study on (60) male and female teachers, including (35) female teachers and (25) male teachers. The following are the methods and results of assuring the validity and Constancy of the scale used.

A. Validity of the Tool

To verify the validity of the questionnaire, the researcher presented it to (8) arbitrators of professors of psychology, curricula, teaching methods, and educational administration in several Jordanian universities since the researcher works as a faculty member at Amman Arab University / Jordan. They were asked to give their opinions on how suitable the study sample's method is expressed in terms of clarity, accuracy, and linguistic formulation. The extent to which the paragraph is appropriate for the dimension that it falls under while highlighting the arbitrators' opinions, some paragraphs of the method have been amended, and the paragraphs that have $(80 \%)$ agreement of the total of the arbitrators were preserved. Also, the expressions that did not obtain this percentage were deleted.

B. Validity of variable

The researcher calculated the correlation coefficients between each statement and the total degree of the scale and the correlation coefficient of each statement with the dimension to which it belongs, in addition to calculating the correlation coefficient of each dimension with the total score of the scale. As a result, it became clear that the correlation coefficients ranged between ( 0.25 and o.8o). Moreover, they were all a function at the level of $(\alpha=0.5)$ except for (10) ten expressions that were not a function of their correlation with the total score of the scale, which the researcher deleted so that the scale would be in its final form after deleting the statements consisting of $(50)$ phrases after what was in its initial form consisting of (6o) Phrase.

C. Reliability

The reliability of the scale dimensions in its final form was calculated using the Cronbach Alpha equation between the degrees of the dimension and the total degree of the scale; however, the reliability coefficient of the scale as a whole reached (0.845), which is a large degree of stabilityindicating the stability of the scale.

\subsubsection{The Study Results and its Discussion}

Results of the first question: What are the attitudes of primary school teachers (males and females) in Mubarak Al-Kabeer Educational District towards the teaching profession?

To answer that question, the researcher extracted the arithmetic average and the standard deviation of the responses of the study sample individuals on the scale of the attitude towards the teaching profession and calculated the value of the " $\mathrm{T}$ " test to indicate the differences between the arithmetic average of the sample and the hypothetical arithmetic average. Therefore Table (2) shows the differences between the average sample grade scores and the hypothetical arithmetic average.

Table 2: The significance of the differences between the average sample grade scores and the hypothetical arithmetic average

\begin{tabular}{|c|c|c|c|c|c|}
\hline Function level & "t" value & hypothetical arithmetic average & Standard deviation & Arithmetic average & Sample no. \\
\hline o.oo1 $^{*}$ & 14.25 & 150 & 23.72 & 118.80 & 400 \\
\hline
\end{tabular}

It is obvious from Table (2) that the average sample population was (118.80), the standard deviation (23.72), and that the hypothetical mean (150) is greater than the arithmetic average of the sample members, and the value of "T" was statistically significant at the level of (o.oo1). However, this indicates That the sample members have a negative attitude towards the teaching profession. 
Therefore, the results of this study are consistent with the results of (Osunde \& Izevbigie, 2006) whose results indicated a negative attitude towards the teaching profession. Also, the current study results differed from the study of (Al-Mjedil and Al-Sharia, 2012; and Abdul-Rahman study, 2014), whose results indicated a positive attitude towards the teaching career for the study samples.

Results of the second question: Are there statistically significant differences at the level of significance $(\alpha \leq 0.05)$ in the attitudes of primary school teachers (males and females) in Mubarak AlKabeer educational district according to the gender variable (males, females)?

To answer that question, the researcher extracted the average grades of male and female teachers and calculated the significance of the differences using the " $\mathrm{T}$ " test for two independent groups. Table (3) shows the importance of the differences between the average grades of male and female teachers in the teaching profession.

Table 3: The significance of the differences between the average grades of male and female teachers towards the teaching profession

\begin{tabular}{lllllll} 
Gender & $\mathbf{N}$ & Mean & Hypothetical mean & Standard deviation & “T”value & Sig \\
\hline Males & 170 & 105.50 & 150 & 22.27 & 6.50 & 0.001 \\
Females & 230 & 132.10 & 150 & 25.17 & & \\
Total & 400 & & & & &
\end{tabular}

It is obvious from Table (3) that there are statistically significant differences at the level of significance (o.oo1) in the attitudes of the sample members on the total score of the method. Which the calculated on the overall method as a whole, the value of " $t$ " was (6.50), which is a statistically significant value at the level of significance (o.oo1) depending on the gender variable and in advantage for females. The researcher may attribute this to the fact that females are more inclined into the teaching career than males, also because the teaching profession is one of the desired professions for females, the most acceptable in Kuwaiti society, and commensurate with the nature of females, as well as the suitability of permanence in this career for females in terms of working hours and frequent holidays, makes this profession attractive to females.

The results of this study agree with the results of (Al-Khalidi, 2013; Al-Mjedil and Al-Sharia, 2012; Al-Amayreh and Al-Asha, 2009; Khalil and Sherir, 2008; Al-Sharaa and Al-Baqer, 2000) studies, whose results indicated that there are statistically significant differences towards the teaching career, in advantage for females. However, it differed from the results of the (Abdul-Rahman, 2014) study, whose results indicated no statistically significant differences towards the teaching career according to the gender variable.

Table 4: The significance of the differences between the average degrees of teachers of literary majors and scientific majors towards the teaching profession

\begin{tabular}{|l|l|c|c|c|c|c|}
\hline Majors & No. & Standard deviation & Hypothetical arithmetic average & Arithmetic average & "t"Value & Function level \\
\hline Literary & 210 & 20.60 & 150 & 128.50 & \multirow{2}{*}{ Non- } & fon \\
\cline { 1 - 4 } Scientific & 190 & 18.70 & 150 & 121.90 & & functional \\
\hline
\end{tabular}

It is evident from Table (4) that the mean value for the degree of literary majors was (128.50), with a standard deviation (20.60), while the arithmetic average for the degree of science majors was (121.90), and with a standard deviation of (18.70). So, by calculating the value of "T", it turned to be (1.15); it is a non-statistically significant value, which indicates that there are no statistically significant differences between the average degrees of the (males and females) teachers of literary majors and the (males and females) teachers of scientific majors towards the teaching profession.

The results of this study are consistent with the study of (Al-Shahwani, 2004; Al-Ruz and Mraje', 
2019; Al-Mjedil and Al-Sharia, 2012), whose results showed that there are no differences between literary and scientific major's teachers towards the teaching profession. At the same time, they differed with the study of (Al-Mjedil, 2006) that explained the results of his study that there are differences towards the teaching profession between literary and scientific majors with an advantage for academic majors. The researcher explains this result as the proper preparation of teachers should not be limited to building cognitive and skill aspects but rather to build positive attitudes related to mastery and creativity in the profession.

Table 5: Arithmetic averages and standard deviations to acknowledge the indication of the service on the attitudes of primary school teachers (males and females) in Mubarak Al-Kabeer Educational District towards the teaching profession

\begin{tabular}{|c|c|c|c|c|}
\hline Domain & No. & Service & $\begin{array}{l}\text { Arithmetic } \\
\text { average }\end{array}$ & $\begin{array}{l}\text { Standard } \\
\text { deviation }\end{array}$ \\
\hline \multirow[t]{4}{*}{ Job description } & 98 & Less than 5years & 35.15 & 3.47 \\
\hline & 148 & From 5- less than ten years & 31.70 & 3.78 \\
\hline & 154 & More than ten years & 31.96 & 3.49 \\
\hline & 400 & Less than 5years & 32.91 & 3.58 \\
\hline \multirow[t]{4}{*}{ Self-satisfaction } & 98 & From 5 - less than ten years & 31.00 & 2.51 \\
\hline & 148 & More than ten years & 28.28 & 2.20 \\
\hline & 154 & Less than 5years & 28.50 & 2.63 \\
\hline & 400 & From 5- less than ten years & 29.26 & 2.44 \\
\hline \multirow[t]{4}{*}{ Financial aspects } & 98 & More than ten years & 22.00 & 2.95 \\
\hline & 148 & Less than 5years & 21.20 & 3.19 \\
\hline & 154 & From 5- less than ten years & 20.00 & 2.80 \\
\hline & 400 & More than ten years & 21.07 & 2.98 \\
\hline \multirow[t]{4}{*}{ Relationship with colleagues and superiors } & 98 & Less than 5years & 24.20 & 2.00 \\
\hline & 148 & From 5 - less than ten years & 26.10 & 2.35 \\
\hline & 154 & More than ten years & 24.00 & 2.40 \\
\hline & 400 & Less than 5years & 24.77 & 2.25 \\
\hline \multirow[t]{4}{*}{ Future of the career } & 98 & ${ }_{5}$ From 5 - less than ten years & 38.12 & 4.50 \\
\hline & 148 & More than ten years & 35.18 & 4.90 \\
\hline & 154 & Less than 5years & 35.80 & 5.20 \\
\hline & 400 & From 5 - less than ten years & 36.37 & 4.87 \\
\hline \multirow[t]{5}{*}{ Society's view for the teaching profession } & 98 & More than ten years & 44.02 & 3.98 \\
\hline & 148 & Less than 5years & 38.90 & 4.66 \\
\hline & 154 & From 5 - less than ten years & 40.18 & 4.60 \\
\hline & 400 & & 41.02 & 4.41 \\
\hline & 98 & Less than 5years & 32.415 & 3.235 \\
\hline \multirow[t]{3}{*}{ Total } & 148 & From 5 - less than ten years & 30.226 & 3.513 \\
\hline & 154 & More than ten years & 30.073 & 3.520 \\
\hline & 400 & & 30.904 & 3.421 \\
\hline
\end{tabular}

Table 6: Results of the single-variance analysis to indicate the attitudes differences of the sample members towards the teaching profession according to the years of experience variable

\begin{tabular}{cllllll}
$\begin{array}{c}\text { Doman } \\
\mathbf{N} .\end{array}$ & Source of Variation & $\begin{array}{l}\text { Sum of } \\
\text { Squares }\end{array}$ & df & $\begin{array}{l}\text { Mean of } \\
\text { Squares }\end{array}$ & $\begin{array}{l}\text { "t" } \\
\text { value }\end{array}$ & Sig \\
\hline $\mathbf{1}$ & Among groups & 6.2858 & 397 & 3.142 & 6.169 & Statistically Sig \\
& Between groups & 262.884 & 399 & 0.662 & & \\
& Total & 269.170 & 2 & & & \\
\hline $\mathbf{2}$ & Among groups & 17.894 & 397 & 8.947 & 13.365 & \\
& Between groups & 373.684 & 399 & 0.941 & & \\
& Total & 391.579 & 2 & & & \\
& & 265 & & & &
\end{tabular}




\begin{tabular}{|c|c|c|c|c|c|c|}
\hline & $\begin{array}{l}\text { Among groups } \\
\text { Between groups } \\
\text { Total }\end{array}$ & $\begin{array}{l}5.427 \\
268.480 \\
273.907\end{array}$ & $\begin{array}{l}397 \\
399 \\
2\end{array}$ & $\begin{array}{l}2.713 \\
0.676\end{array}$ & 6.753 & Statistically Sig \\
\hline 4 & $\begin{array}{l}\text { Among groups } \\
\text { Between groups } \\
\text { Total }\end{array}$ & $\begin{array}{l}3.901 \\
247.215 \\
251.116 \\
\end{array}$ & $\begin{array}{l}397 \\
399 \\
2 \\
\end{array}$ & $\begin{array}{l}1.950 \\
0.622\end{array}$ & 6.051 & Statistically Sig \\
\hline 5 & $\begin{array}{l}\text { Among groups } \\
\text { Between groups } \\
\text { Total }\end{array}$ & $\begin{array}{l}4.745 \\
297.742 \\
302.488 \\
\end{array}$ & $\begin{array}{l}397 \\
399 \\
2 \\
\end{array}$ & $\begin{array}{l}2.372 \\
7.749\end{array}$ & 3.112 & Statistically Sig \\
\hline 6 & $\begin{array}{l}\text { Among groups } \\
\text { Between groups } \\
\text { Total }\end{array}$ & $\begin{array}{l}3 \cdot 513 \\
334.965 \\
338.478\end{array}$ & $\begin{array}{l}397 \\
397 \\
399 \\
\end{array}$ & $\begin{array}{l}1.756 \\
0.843\end{array}$ & 2.022 & Statistically Sig \\
\hline Total & $\begin{array}{l}\text { Among groups } \\
\text { Between groups } \\
\text { Total }\end{array}$ & $\begin{array}{l}41.738 \\
297.495 \\
178.497 \\
\end{array}$ & $\begin{array}{l}2 \\
397 \\
399\end{array}$ & $\begin{array}{l}20.869 \\
0.749 \\
\end{array}$ & 6.078 & \\
\hline
\end{tabular}

Table (6) shows that there are statistically significant differences in the level of attitudes of the study sample towards the teaching career according to the years of service variable in all fields between those with service (less than five years) and those with service ( 5 - less than ten years), in favor of the group which less than ( 5 years) of service, as well as the existence of statistically significant differences between the category (less than five years) and the category (more than ten years), in favor of the group (less than five years). The researcher attributes the fact that the teachers with service (Less than five years) still look at the teaching career as it fulfills their ambitions and desires, unlike teachers with service (more than ten years) who consider their long service in this profession did not achieve their functional and material aspirations, with increasing tasks on their hindrance.

The results of the study also showed that there are statistically significant differences in the level of teachers 'attitudes towards the teaching profession on the overall grade of the method between those with service (less than five years) and those who have (more than ten years), also in favor of the category (less than five years). The researcher said that this result conveys the fact that male and female teachers with service (less than five years) are still enthusiastic about work. They are distinguished by their high motivation to their career, besides that they have not yet been affected by work pressures, in addition, that they are convinced of the financial income of this profession, as the requirements and costs of life did not constitute a great burden for them, unlike more experienced teachers who feel pressured to work with no realizing their ambitions for higher positions.

The results of this study agree with the results of the study of (Al-Khalidi, 2013), which concluded that (female and male) teachers with less experience show higher levels of satisfaction than their peers with more years of experience. However, the current study results differed from the results of the study of Al-Ajez and Nashwan (2004) and the study of Khalil and Sherir (2008). Their results indicated no statistically significant differences in the experience variable's effect on job satisfaction.

\section{Recommendations and Proposals}

Conduct more studies in education and light of several variables such as emotional intelligence, lifestyle, personality style, post-traumatic growth.

Improve the level of psychological services in civil society institutions and psychological and social support centers that take care of the affairs of male and female teachers through the preparation of counseling and preventive programs and dialogue and group activities to raise the level of practical and scientific skills of teachers.

Increase interest in male and female teachers by preparing more recreational and educational programs to raise awareness and culture. 


\section{Conclusion}

In the end, it can be said that primary school teachers' enjoyment of a positive trend towards the teaching profession in light of the new educational reforms is important to the teacher's performance, and in improving the desired educational outcome on the one hand, and on the other hand, it can be concluded that the teacher, through his positive attitude towards his profession, is satisfied with the teaching profession, and this pushes him to be proud, adhere to it and continue with it, this helps him to overcome professional difficulties and provide what is best in the teaching process. It is concluded that in light of the interest in the teacher financially and morally, the provision of the appropriate educational climate and the improvement of his social status, the teacher's love for his profession is generated or increased, and consequently the positive trend of teaching is strengthened or the negative trend changes to the positive. This is in line with improving the other components of the educational process, such as modifying curricula and teaching methods, and providing them with modern teaching aids, this means that it improves educational outcomes as a whole.

\section{References}

Abdul-Rahman, J. (2014). Attitudes of secondary school teachers towards the teaching profession. Al-Madinah International University Journal: (8): 197-219.

Abdel-Fattah, N. (2010). Evaluating the performance of total quality standards and standards for female students of practical education in scientific departments at King Faisal University in the light of internationalism and its reflection on the trend towards the teaching profession. Journal of Scientific Education: 13(4): 189-239.

Obeidi, Y, \& Ashour, A. (2020). Postgraduate students' attitudes of professors towards the teaching profession and its relationship to their achievement motivation. The Scientific Journal of Educational Sciences and Mental Health: 2 (5): 49-71.

Abla, S., Kayash, F. \& Bin Khaled, A. (2020). Students' attitudes towards the use of the Internet in scientific research. Unpublished Master's Thesis, Ahmed Deraya University, Adrar, Adrar, Algeria.

Ahmed, M. \& Zumrud, A. (2014). The relationship between female students' satisfaction with the kindergarten program and their attitudes towards practicing the profession of educator, a field study from the perspective of the fourth-year students in the Faculty of Education at Tishreen University." Tishreen University Journal of Research and Scientific Studies: 38 (5): 11-30.

Al-Ajmi, L. (2007). The effect of teaching a science teaching method course on developing and learning attitudes towards science among female students of the College of Education for Girls (scientific departments) in Abha, Saudi Arabia. Studies in Curricula and Teaching Methods: (127): 74-118.

Al-Amayreh, M., \& Al-Asha, I. (2009). The level of attitudes of primary school teachers in Jordan to the teaching profession in the light of some variables. Dirasat Journal, University of Jordan, Jordan.

Al-Bariri, R.\& Ishaq, H. (2010). The effectiveness of a proposed program for micro-teaching based on interactive video technology in developing the executive skills of teaching among students of Teachers College at Jazan University. Journal of Scientific Education: 13(6): 27-59.

Al-Faqih, K. (2009). Attitudes of Misurata Teachers College students towards the teaching profession and its relationship to academic achievement. Unpublished Master's Thesis, October 7 University. Misurata, Libya.

Al-Jadri, A. (2007). Descriptive statistics in educational sciences. Amman, Jordan: Dar Al Masirah for publishing, distribution, and printing.

Al-Khalidi, M. (2013). Al-Quds Open University Journal of Educational and Psychological Research and Studies. $1(2): 89-124$.

http://search.shamaa.org/PDF/Articles/PSJaqoueprs/JaqoueprsVoliNo2Y2013/2JaqoueprsVoliNo2Y2013.pdf

Al-Mjedil, A. \& Al-Sharia, S. (2012). Attitudes of students of the College of Education towards the teaching profession: A comparative field study between the College of Education - Kuwait University and the College of Education in Hasaka - Al Furat University as a model Damascus University Journal: 28(4): 17-57.

Al-Mjedil, A. (2006). Attitudes of students of education colleges in the Sultanate of Oman towards the teaching profession - a field study - the College of Education in Salalah as a model. Educational Journal, 21 (81): 91142.

Al-Rashed, I. (2003). Attitudes of teachers' college students in Saudi Arabia towards the teaching profession and its relationship to some variables. King Saud University Journal: 15(1): 1-57. 
Al-Ruz, I. \&, Mraje', A. (2019). Attitude towards the teaching profession among students of the College of Education (Al-Bayda) and its relationship to some variables. Research Journal: (13): 427-454.

Al-Sharaa, H. \& Al-Baqer, J. (2000). Teachers' attitudes to the teaching profession in the State of Qatar and how they are affected by some demographic factors. Educational Journal: 14(56): 153-184.

Andronache, D. \& Bacos, M. \& Bacos, V. \& Marci, C. (2014). Attitudes towards teaching profession. Social and Behavioural Science, $142(1): 628-632$

Bayraktar, S. (2012). Attitude towards the teaching profession among students of the College of Education and its relationship to some variables. Tikrit University Journal of Science: 19(7): 567-601.

Heij, A. (2009). The level of understanding of students of education students at the University of Al-Hodeidah of the basic concepts needed to teach physics at the secondary stage and its relationship to their attitudes towards the teaching profession.

Khalil, J. \& Sherir, A. (2008). Job satisfaction and its relationship to some variables among teachers. Journal of the Islamic University: 16(1): 683-711.

Kyriacou, C., and Kunc, R. (2007) Beginning Teacher's Expectations of Teaching, Teaching and Teacher Education, An International Journal of Research and Studies, 23 (8): 1246 - 1257.

Al- Makhzoumi, N. (2007). The effect of the study at the Faculty of Educational Sciences at Zarqa Private University on the attitudes of students of classroom teacher specialization towards the teaching profession. Journal of the College of Education: (7): 457-482.

Musa, A. \& Bichi, A. (2015). Assessment of Prospective Teachers Attitudes towards Teaching Profession: The Case of Northwest University, Kano Nigeria. Journal of Research \& Method in Education, 5 (3): 17-24

Nouri, H. (2011). Measuring the attitudes of the students of the Department of Physics at the College of Education at the University of Basra towards the teaching profession. The Journal of the Prophet and the Qur'an Dhikr: (9): 87.

Osunde, A. U., \& Izevbigie, T. I. (2006). An assessment of teachers' attitude towards teaching profession in Midwestern Nigeria. Education, 126(3): 462-468.

Santillan, A. \& Garcia, E. \& Castro, J \& Abdala, Z. \& Trejo, G. (2012). Cognitive Affective and Behavioural Component That Explain Attitude Toward Statistics. Journal of Mathematics Research, 4 (5). 8-15

Shaheen, A. (2010). Attitudes of Islamic University students towards teaching methods, practical education and the teaching profession in the light of some variables, Journal of Educational Sciences: (1):355-4.3.

Al-Shahwani, A. (2004). Attitudes of the students of the College of Education in Makkah Al-Mukarramah towards the teaching profession. Muscat Seminar The requirements of the education strategy in preparing the Arab teacher.

Sivacumar, A. (2018). Attitudes towards teaching among school teachers in Coimbatore district. Review of Research, 7 (1): 1-6

Sykes, G. (2016). Reform of and as professional development: Phi Delta Kappan, 77(7): 464 .

Tayyab, M. (2012). The trend towards the teaching profession and its relationship to the teaching performance of physical education and sports teachers in secondary education. The Academy for Social and Human Studies: 4(2): 135-146.

Al-Ajez, F. \& Nashwan, J. (2004). Satisfaction factors and developing the effectiveness of teachers' performance in UNRWA schools in Gaza, research presented to the First Educational Conference, (1), 368-398. 